\title{
Ionised and Total Magnesium Serum Concentrations in Renal and Hepatic Diseases
}

\author{
Wolf R. Külpmann' ${ }^{1}$ Jan Rößler ${ }^{1}$, Reinhard Brunkhorst ${ }^{2}$ and Andreas Schüler ${ }^{3}$ \\ 1 Institut für Klinische Chemie I \\ 2 Abteilung Nephrologie \\ 3 Abteilung Gastroenterologie und Hepatologie \\ Medizinische Hochschule Hannover, Hannover, Germany
}

Dedicated to Prof. Dr. Dr. J. Büttner on the occasion of his 65 th birthday

Summary: Ionised and total magnesium concentrations were determined in the serum of different groups of patients suffering from renal or hepatic diseases. Ionised magnesium was measured by Microlyte 6 (KONE, Espoo, Finland) and total magnesium by atomic absorption spectrometry.

In renal insufficiency ionised and total magnesium concentrations were almost equally increased. In proteinuria with a normal glomerular filtration rate, "pseudohypomagnesaemia" was observed, i. e. decreased total magnesium concentration in parallel with a decreased albumin concentration with no significant change in the concentration of ionised magnesium.

Hypermagnesaemia occurred in liver diseases combined with renal insufficiency, whereas "pseudohypomagnesaemia" was most often found in the absence of renal failure. Also treatment with an aldosterone antagonist was associated with a normal ionised magnesium concentration, but the total magnesium concentration was decreased; when additional magnesium was administered, the total magnesium concentration approached a normal value, while ionised magnesium slightly exceeded reference values. Only during cyclosporin treatment did both ionised and total magnesium concentrations become lowered. However, the decrease of total magnesium exceeded that of ionised magnesium due to concomitant hypoalbuminaemia with reduction of the protein-bound fraction. It is concluded that especially low total magnesium concentrations should be investigated by measurement of ionised magnesium to exclude "pseudohypomagnesaemia".

\section{Introduction}

Renal as well as hepatic diseases may have an impact on magnesium balance. As long as only total magnesium concentration could be determined $(1-7)$, there were always some doubts as to whether alterations reflected changes of the ionised (unbound) magnesium concentration or the protein-bound concentration. As in the case of calcium, a decrease or an increase of the ionised magnesium concentration may be considered as a "true" change, whereas a decrease of the total magnesium concentration due to a reduction of protein-bound magnesium might be called a "pseudohypomagnesaemia". On the other hand, the total magnesium concentration may lie within the reference interval, while the ionised concentration, reflecting the active magnesium ions, is lowered, because of complex binding, e.g. to citrate in the event of massive transfusion of blood during liver transplantation (8). In this study, ionised and total magnesium concentrations in the serum were determined in patients suffering from liver or kidney diseases, to determine the circumstances in which the concentration of active magnesium ions is decreased or the less meaningful pseudohypomagnesaemia may be expected.

\section{Materials and Methods}

Patients

Renal discases

1. Group (RD 1): 21 patients (14 male) with renal diseases (tab. 1) and hypoalbuminaemia (albumin in the serum $<37 \mathrm{~g} / \mathrm{l}$ ) but "normal" creatinine clcarance (after adjustment to $1.73 \mathrm{~m}^{2}$ body surface) were investigated (tab. 2). Patients suffering at the same time from gastro-intestinal diseases, hypo- or hyperthyroidism or diabetes mellitus were excluded, as well as paticnts treated with cyclosporin (only two cases), cisplatin or calcium concentrations exceeding $2.60 \mathrm{mmol} / 1 \mathrm{serum}$.

2. Group (RD 2): 29 patients (19 male) with renal diseases (tab. 1), hypoalbuminaemia and decreased creatinine clearance (adjusted to $1.73 \mathrm{~m}^{2}$ body surface) were investigated (tab. 2). They were under treatment with furosemide (mean dosage $103 \mathrm{mg} / \mathrm{d}$; range $40-250 \mathrm{mg} / \mathrm{d}$ ). For exclusion critcria see RD 1 . 
Tab. I Patients with renal discases

\begin{tabular}{ll}
\hline Diagnosis & $\begin{array}{l}\text { No. of } \\
\text { patients }\end{array}$ \\
\hline Minimal change glomeruloncphritis & 10 \\
Membranous glomerulonephritis & 16 \\
Focal-segmental glomerulonephritis & 5 \\
Focal-scgmental mesangioproliferative & 2 \\
$\quad$ glomerulonephritis & 5 \\
Membranoproliferative glomerulonephritis & \\
$\quad$ Type 1 & 3 \\
Systemic lupus erythematosus & 6 \\
Mesangioproliferative glomerulonephritis & \\
$\quad$ IgA) & 1 \\
Panarteriitis nodosa & 1 \\
Amyloidosis & 1 \\
Proteinuria (unknown origin) & \\
\hline
\end{tabular}

2. Group (LD 2): 20 patients (13 male) with hypoalbuminaemia and incrcased creatinine concentration in the serum, treated with furosemide (mean dosage $76 \mathrm{mg} / \mathrm{d}$; range $20-240 \mathrm{mg} / \mathrm{d}$ ) (tab. 4).

3. Group (LD 3): 11 patients (5 male) after orthotopic liver transplantation with hypoalbuminaemia, treated with cyclosporin (cyclosporin in serum: mean $115 \mu \mathrm{g} / \mathrm{l}$; range $59-161 \mu \mathrm{g} / \mathrm{l}$ ) (tab. 4).

4. Group (LD 4): 26 patients ( 17 male), with hypoalbuminaemia, treated with furosemide (mean dosage $45 \mathrm{mg} / \mathrm{d}$; range $20-80$ $\mathrm{mg} / \mathrm{d}$ ) and spironolactone (mean dosage $115 \mathrm{mg} / \mathrm{d}$; range 50-200 $\mathrm{mg} / \mathrm{d})$ (tab. 4).

5. Group (LD 5): 9 patients (4 male) with hypoalbuminaemia, treated with spironolactone (mean dosage $83 \mathrm{mg} / \mathrm{d}$; range 50-200 $\mathrm{mg} / \mathrm{d})$ (tab. 4).

6. Group (LD 6): 15 patients ( 9 male) with hypoalbuminaemia treated with furosemide (mean dosage $50 \mathrm{mg} / \mathrm{d}$; range 20-120 $\mathrm{mg} / \mathrm{d}$ ), spironolactone (mean dosage $96 \mathrm{mg} / \mathrm{d}$; range $50-200 \mathrm{mg} / \mathrm{d}$ ) and magnesium p. o. (Magnesium Verla ${ }^{\mathrm{TM}}$ : mean dosage $112 \mathrm{mg} / \mathrm{d}$; range $80-240 \mathrm{mg} / \mathrm{d}$ ) (tab. 4).

Tab. 2 Renal discases

\begin{tabular}{lcccc}
\hline & 1. Group (RD 1) & 2. Group (RD 2) \\
\hline No. of patients & 21 & & 29 & 19 \\
male & 14 & & 10 & Range \\
female & 7 & & Mean & 11 \\
\hline Property & Mean & Range & 46.1 & -73 \\
\hline Age (years) & 33.7 & $9-54$ & 53.9 & -73 \\
Creatinine clearance (ml/min) & 164.6 & $93-288$ & 57.6 & 34 \\
S-Protein $(\mathrm{g} / \mathrm{l})$ & 53.4 & $36-80$ & 28.9 & 10 \\
S-Albumin $(\mathrm{g} / \mathrm{l})$ & 25.2 & $14-36$ & 7.19 & $2.98-12.10$ \\
S-Cholinesterase $(\mathrm{kU} / \mathrm{l})$ & 7.16 & $3.22-10.92$ & 8.5 & $4.9-12.2$ \\
S-Cholesterol (mmol/l) & 9.6 & $4.0-19.2$ & 3.18 & $1.22-8.20$ \\
S-Triacylglycerol (mmol/l) & 3.34 & $0.78-7.26$ & 6.66 & $0.41-16.00$ \\
U-Protein $(\mathrm{g} / \mathrm{d})$ & 5.59 & $0.03-15.96$ & & \\
\hline
\end{tabular}

Tab. 3 Patients with diseases of the liver

\begin{tabular}{lc}
\hline Diagnosis & $\begin{array}{c}\text { No. of } \\
\text { patients }\end{array}$ \\
\hline Chronic active hepatitis B & 16 \\
Chronic active hepatitis C & 23 \\
Chronic active hepatitis B and C & 4 \\
Alcohol toxic liver cirrhosis & 28 \\
Toxic liver cirrhosis (apart from alcohol toxic) & 5 \\
Autoimmune hepatitis & 5 \\
Primary biliary cirrhosis & 9 \\
Primary sclerotic cholangitis & 6 \\
$\alpha_{1}$-Proteinase inhibitor deficiency & 1 \\
M. Wilson & 2 \\
Budd-Chiari syndrome & 2 \\
Liver cirrhosis (unknown origin) & 9 \\
Liver transplantation & 11 \\
Carcinoma of the liver/liver metastases & 11 \\
\hline
\end{tabular}

\section{Liver discases}

The following groups with liver diseases were examined (for exclusion criteria see $R D$ 1):

1. Group (LD 1): 51 patients ( 31 male) with diseases of the liver (tab. 3) and hypoalbuminaemia, but "normal" creatinine concentration in the serum (tab. 4).
The groups were compared with a group of 60 blood donors, who were selected according to the guidelines (9) and matched for age (mean \pm standard deviation (years): $46.5 \pm 12.2)$ ) and sex (34 male, 26 female).

\section{Sampling}

Blood was obtained from the patients and the blood donors between 7 a. m. and 9.30 a. m. by venipuncture with Monovettes (Sarstedt, Nümbrecht). The serum was separated after centrifugation $\left(25^{\circ} \mathrm{C}, 1200 \mathrm{~g}\right)$ and stored in a refrigerator (max. 5 days), if analyses could not be performed at once.

\section{Sample preparation}

Serum for ionised magnesium measurement was adjusted to $\mathrm{pH}$ $7.40 \pm 0.05$ by bubbling $\mathrm{CO}_{2}$ gas prior to analysis.

\section{Methods}

\section{lonised magnesium}

The concentration of ionised magnesium in the serum was determined by Microlyte 6 (KONE, Espoo, Finland). The ion-selective electrode which was used for the measurement had a modified ETH 5220-containing PVC membrane. An Ag/AgCl-electrode was used as a reference electrode. The ionised calcium concentration was determined simultaneously, since this is needed to account for 
Tab. 4 Liver diseases

\begin{tabular}{|c|c|c|c|c|c|c|c|}
\hline \multirow[b]{2}{*}{$\begin{array}{l}\text { No. of patients } \\
\text { male } \\
\text { female }\end{array}$} & \multicolumn{2}{|c|}{ 1. Group (LD 1) } & \multicolumn{2}{|c|}{ 2. Group (LD 2) } & \multicolumn{3}{|c|}{ 3. Group (LD 3) } \\
\hline & $\begin{array}{l}51 \\
31 \\
20\end{array}$ & & $\begin{array}{r}20 \\
13 \\
7\end{array}$ & & $\begin{array}{r}11 \\
5 \\
6\end{array}$ & & \\
\hline Property & Mean & Range & Mean & Range & Mean & Rang & \\
\hline $\begin{array}{l}\text { No. of patients } \\
\text { male } \\
\text { female }\end{array}$ & $\begin{array}{r}26 \\
17 \\
9\end{array}$ & & $\begin{array}{l}9 \\
4 \\
5\end{array}$ & . & $\begin{array}{r}15 \\
9 \\
6\end{array}$ & & \\
\hline $\begin{array}{l}\text { Age (years) } \\
\text { S-DeRitis ratio }{ }^{\prime} \\
\text { S-Cholinesterase (kU/l) } \\
\text { S-Albumin (g/l) } \\
\text { S-Bilirubin ( } \mu \mathrm{mol} / 1) \\
\text { P-Prothrombin time (\%) } \\
\text { S-Creatinine }(\mu \mathrm{mol} / 1)\end{array}$ & $\begin{array}{l}52.2 \\
1.28 \\
1.95 \\
27.9 \\
81.0 \\
60.1 \\
70.1\end{array}$ & $\begin{array}{l}30-70 \\
0.59-2.00 \\
0.81-4.31 \\
18-35 \\
4-410 \\
37-100 \\
40-92\end{array}$ & $\begin{array}{c}42.8 \\
1.45 \\
1.80 \\
28.1 \\
108.8 \\
65.1 \\
53.8\end{array}$ & $\begin{array}{l}16-60 \\
0.87-2.67 \\
0.81-4.31 \\
20-33 \\
15-371 \\
44-99 \\
44-91\end{array}$ & $\begin{array}{l}52.7 \\
1.22 \\
1.80 \\
29.4 \\
65.6 \\
62.7 \\
63.2\end{array}$ & $\begin{array}{l}31 \\
0.52 \\
0.82 \\
18 \\
11 \\
28 \\
40\end{array}$ & $\begin{array}{l}-69 \\
2-\quad 1.90 \\
2-5.60 \\
-35 \\
-183 \\
-93 \\
-91\end{array}$ \\
\hline
\end{tabular}

1) S-Aspartate aminotransferase/S-Alanine aminotransferase

the common calcium interference of the magnesium electrode. As the degree of interference may change with time, the actual degree at the time of measurement was determined by measurement of standards (without protein) containing different concentrations of calcium and magnesium just prior to the determination. Ionised magnesium concentrations are reported for the actual $\mathrm{pH}$ of the sample and for $\mathrm{pH} 7.40$ after calculation by a built-in computer. In this study ionised magnesium concentration is given after adjusting to $\mathrm{pH} 7.4$, to make comparison with the reference interval easier.

\section{Other quantities}

Ionised calcium, $\mathrm{pH}$, ionised sodium and ionised potassium in serum were determined simultaneously with ionised magnesium by Microlyte 6 (KONE, Espoo, Finland).

Total magnesium in serum and urine was determined by atomic absorption spectrometry (AAS 1100 , Perkin-Elmer, Überlingen), at $285.2 \mathrm{~nm}$ after addition of $\mathrm{LaCl}_{3}$.

Albumin concentration in serum was determined by immunochemistry (Array, Beckmanan Instr., München).

Creatinine concentration in serum was measured enzymatically (Hitachi 747, Boehringer Mannheim, Mannheim).

Total calcium was determined after reaction with cresolphthalein complexone (Hitachi 747, Boehringer Mannheim, Mannheim).

Total protein in serum was measured bichromatically by the biuret reaction (Hitachi 747, Boehringer Mannheim, Mannheim).

Cholesterol and triacylglycerol in serum were determined enzymatically (Hitachi 747, Boehringer Mannheim, Mannheim).

Bilirubin was measured bichromatically after reaction with 2.5dichlorphenyldiazonium salt (Hitachi 747, Boehringer Mannheim, Mannheim).
Enzymes (aspartate aminotransferase, alanine aminotransferase, cholinesterase) were determined according to the standard procedures of the German Society for Clinical Chemistry.

Creatinine concentration in urine was measured by Jaffe's reaction (Elan, Eppendorf, Hamburg).

Total protein in urine was determined with the biuret reaction after precipitation with trichloroacetic acid and blank correction.

\section{Quality assessment}

\section{Precision}

Kontrollogen-L (lot 623136) (Behring, Frankfurt/M.), and Qualitrol Precision (Merck, Darmstadt) were used for assessment of precision. All measurements of the ionised magnesium concentrations were performed in duplicates, which were accepted, if their values differed by less than $2 \%$.

\section{Statistics}

Data of the different groups were compared by analysis of covariance and Scheffë's test (10). Adequate Gaussian distribution was tested by the Kolmogorov-Smirnov-test.

\section{Results}

\section{Quality assessment}

\section{Precision}

Two control sera were analysed on 10 consecutive days in duplicate. The coefficient of variation for ionised 
Tab. 5 Precision within days

\begin{tabular}{llll}
\hline Specimen & $\begin{array}{l}\text { Number } \\
\text { of deter- } \\
\text { minations }\end{array}$ & $\begin{array}{l}\text { Mean } \\
\text { value } \\
(\mathrm{mmol} / \mathrm{l})\end{array}$ & $\begin{array}{l}\text { Relative } \\
\mathrm{SD}^{1)}(\mathrm{CV})^{2)} \\
(\%)\end{array}$ \\
\hline & \multicolumn{3}{l}{ lonised $\mathrm{Mg}$ concentration } \\
Kontrollogen L & 10 & 0.534 & 2.2 \\
Qualitrol Precision & 10 & 0.547 & 2.0 \\
& lonised Ca concentration \\
Kontrollogen L & 10 & 1.18 & 1.8 \\
Qualitrol Precision & 10 & 1.30 & 1.5 \\
& $H^{+}$ion concentration \\
Kontrollogen L & 10 & $6.5 \cdot 10^{-5}$ & 7.8 \\
Qualitrol Precision & 10 & $7.0 \cdot 10^{-6}$ & 8.6 \\
\hline
\end{tabular}

1) Standart deviation

2) Coefficient of variation

magnesium based on mean values was $2.2 \%$ and $2.0 \%$ (tab. 5).

\section{Accuracy}

Reference method values were not yet available to test - accuracy. The following may be considered as indicators of accuracy.

1. Magnesium concentration in ultrafiltrates exceeded ionised magnesium concentration by $4.9 \%$ (2).

2. Reference values obtained by an indirect method, by the same or a different ion-selective electrode were similar (tab. 6).

\section{Clinical study}

\section{Reference interval}

The reference intervals for total and ionised magnesium were calculated from data of 60 healthy blood donors and include the range between the 2.5th and 97.5th percentile (tab. 6). There was no significant influence of age or sex on the reference interval of ionised and total magnesium nor on the pertinent ratio as proven by analysis of covariance. The same held true for the following groups of patients.

\section{Renal diseases}

Ionised and total magnesium concentrations in the serum of patients suffering from renal diseases are presented in table 7.

In patients with proteinuria (RD 1) and decreased albumin concentration in the serum, the total magnesium concentration was $9 \%$ lower (statistically significant) than in the reference group, whereas the ionised magnesium concentration was almost identical $(-1 \%$, statistically not significant); therefore the percentage of ionised magnesium was increased. Figure 1 indicates that total magnesium is dependent on albumin concentration,
Tab. 6 Reference intervals

\begin{tabular}{|c|c|c|c|}
\hline Property & $\begin{array}{l}\text { Reference } \\
\text { interval } \\
(\mathrm{mmol} / \mathrm{l})\end{array}$ & Method & Author \\
\hline \multirow[t]{5}{*}{ Ionised $\mathrm{Mg}$} & $0.43-0.66\left(\delta^{7}\right)$ & UC-ER & \multirow{5}{*}{$\begin{array}{l}\text { Speich } \\
\text { et al. (12) } \\
\text { Speich } \\
\text { et al. (12) } \\
\text { Altura } \\
\text { et al. (4) } \\
\text { Maj-Zurawska } \\
\text { et al. (13) } \\
\text { this study }\end{array}$} \\
\hline & $0.45-0.66(q)$ & UC-ER '; & \\
\hline & $0.53-0.67$ & $\begin{array}{l}\text { ISE } \\
\text { (Nova) }\end{array}$ & \\
\hline & $0.54-0.74$ & $\begin{array}{l}\text { ISE } \\
\text { (KONE) }\end{array}$ & \\
\hline & $0.51-0.66$ & $\begin{array}{l}\text { ISE } \\
\text { (KONE) }\end{array}$ & \\
\hline \multirow[t]{5}{*}{ Total Mg } & $0.77-1.03\left(\delta^{7}\right)$ & AAS & \multirow{5}{*}{$\begin{array}{l}\text { Speich } \\
\text { et al. (12) } \\
\text { Speich } \\
\text { et al. (12) } \\
\text { Altura } \\
\text { et al. (4) } \\
\text { Maj-Zurawska } \\
\text { et al. (13) } \\
\text { this study }\end{array}$} \\
\hline & $0.73-1.06$ (q) & AAS & \\
\hline & $0.70-0.96$ & AAS & \\
\hline & $0.70-0.98$ & AAS & \\
\hline & $0.69-0.92$ & AAS & \\
\hline \multirow{6}{*}{$\frac{\text { Ionised } \mathrm{Mg}}{\text { Total } \mathrm{Mg}}$} & $0.53-0.69\left(\mathrm{~d}^{3}\right)$ & UC-ER/ & \multirow{2}{*}{$\begin{array}{l}\text { Speich } \\
\text { et al. (12) }\end{array}$} \\
\hline & & AAS & \\
\hline & $0.55-0.69$ (P) & $\begin{array}{l}\text { UC-ER/ } \\
\text { AAS }\end{array}$ & \multirow{4}{*}{$\begin{array}{l}\text { Speich } \\
\text { et al. (12) } \\
\text { Altura } \\
\text { et al. (4) } \\
\text { Maj-Zurawskc } \\
\text { et al. (13) } \\
\text { this study }\end{array}$} \\
\hline & $0.61-0.85$ & ISE/AAS & \\
\hline & $0.65-0.80$ & ISE/AAS & \\
\hline & $0.65-0.77$ & ISE/AAS & \\
\hline
\end{tabular}

AAS: atomic absorption spectrometry

ISE: ion-selective electrode

UC-ER: difference between magnesium concentration in supernatant after ultracentrifugation (determined by AAS) and complexed magnesium concentration as obtained from exchange resin (ER) (determined by AAS).

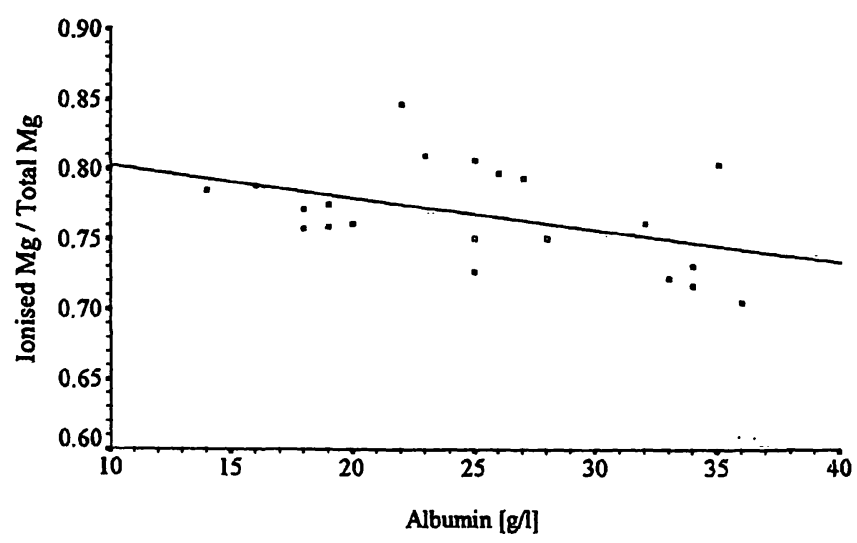

Fig. 1 Fraction of ionised $\mathrm{Mg}$ and albumin in renal diseases (RD 1)

Slope: -0.002 Intercept 0.83 Coefficient of correlation: -0.44 RD 1: Renal disease.

whereas the ionised magnesium concentration is not influenced.

In renal insufficiency ( $R D$ 2) both, the ionised and total magnesium concentration in the serum were equally ele- 
Tab. 7 Renal diseases: Magnesium in the serum, $\bar{x}( \pm s)$

\begin{tabular}{llll}
\hline Property & Control $\left.^{1}\right)$ & $\begin{array}{l}\text { 1. Group } \\
(\mathrm{RD} \mathrm{1)} \\
(\mathrm{n}=21)\end{array}$ & $\begin{array}{l}\text { 2. Group } \\
(\mathrm{RD} \mathrm{2}) \\
(\mathrm{n}=29)\end{array}$ \\
\hline $\begin{array}{c}\text { Total } \mathrm{Mg} \\
(\mathrm{mmol} / \mathrm{l})\end{array}$ & $0.80(0.06)$ & $0.73(0.05)[-]$ & $0.93(0.09)[+]$ \\
$\begin{array}{c}\text { Ionised } \mathrm{Mg} \\
(\mathrm{mmol} / \mathrm{l})\end{array}$ & $0.57(0.04)$ & $0.56(0.04)$ & $0.65(0.05)[+]$ \\
$\frac{\text { Ionised Mg }}{\text { Total } \mathrm{Mg}}$ & $0.71(0.03)$ & $0.77(0.04)[+]$ & $0.71(0.05)$ \\
\hline
\end{tabular}

[ ] Statistically significant negative [ - ] or positive [ + ] deviation as compared with the mean of the control group

1) Control: Reference group of healthy blood donors

RD 1: Renal disease; creatinine concentration in the serum within reference interval

RD 2: Renal disease; creatinine concentration in the serum exceeding reference interval

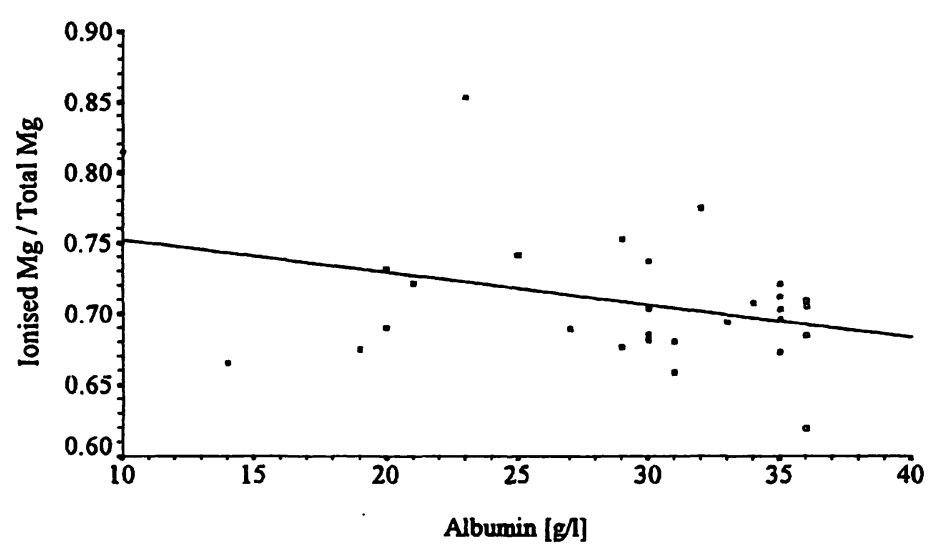

Fig. 2 Fraction of ionised $\mathrm{Mg}$ and albumin in renal diseases (RD 2)

Slope: -0.002 Intercept: 0.78 Coefficient of correlation: -0.35 RD 2: Renal insufficiency.

vated $(+15.6 \%$ vs $+16.2 \%)($ tab. 7$)$ as compared with the reference group, and the fraction of ionised magnesium was unchanged. Nevertheless, the dependency of total magnesium on albumin concentration in the serum was still obvious (fig. 2). Magnesium excretion in the urine was below the reference interval (2.5-8.5 $\mathrm{mmol} / \mathrm{d}$ ) and lower than in the patients with proteinuria (RD 1), but the mean fractional excretion $(7.0 \% \pm 3.9 \%$ (standard deviation)) exceeded group RD 1 (3.5\% $\pm 1.2 \%$ (standard deviation)).

\section{Liver diseases}

Ionised and total magnesium concentrations in the serum of patients suffering from liver diseases are presented in table 8.

In group LD 1 with normal renal function but with hypoalbuminaemia, the total magnesium concentration was decreased by $6.2 \%$ as compared with the reference interval, and the ionised magnesium concentration was decreased by only $2.7 \%$ (statistically not significant). Hence, the ionised magnesium fraction was elevated. It may be concluded that total magnesium is correlated with the albumin concentration (fig. 3), whereas ionised magnesium is not significantly affected.

In liver diseases combined with renal insufficiency (and therapy with furosemide), LD 2 results resembled RD 2: the mean concentration of ionised and total magnesium were increased similarly $(17 \%$ vs $13.8 \%)$, and the ionised magnesium fraction was not significantly changed. Correlation of total magnesium and albumin concentration may be supposed from figure 4 .

In patients treated with cyclosporin (LD 3), the decrease of total magnesium concentration exceeded the decrease of ionised magnesium $(-17.5 \%$ vs $-11.3 \%)$, and the fraction of ionised magnesium was significantly elevated $(7.0 \%)$. Its correlation with albumin is presented in figure 5.

In cases of treatment with furosemide and spironolactone (LD 4) only the total magnesium concentration was significantly changed $(-7.5 \%)$ and hence the fraction of ionised magnesium was elevated $(+5.6 \%)$. It was poorly correlated with the albumin concentration (figure 6).

During therapy of 9 patients with spironolactone as the only diuretic (LD 5), ionised magnesium was slightly decreased $(1.9 \%)$, but total magnesium was clearly (8.8\%) lowered (but statistically not significant with only 9 patients), and the fraction of free magnesium was significantly elevated. Because of the small number of patients the correlation with albumin may be misleading and is not shown.

In patients treated with diuretics and substituted with magnesium (LD 6), ionised magnesium was not significantly elevated, total magnesium not significantly lowered, and the fraction of ionised magnesium not significantly increased but correlated with the albumin concentration (fig. 7).

\section{Discussion}

Before starting the study the reliability of the measurement of ionised magnesium was evaluated. According to the guidelines (11), the pertinent coefficient of variation should not exceed $2.1 \%$. In fact $2.2 \%$ and $2.0 \%$ were achieved. Accuracy could not be directly checked as no appropriate control sera are available. But there was indirect evidence that determinations were accurate (see results). Precision and accuracy of the other methods was better than required by the guidelines (11) (data not shown).

Blood samples from all individuals were taken between 7 a. m. and 9.30 a.m. to exclude any influence of possible circadian rhythms. 
Tab. 8 Liver diseases: Magnesium in the serum, $\vec{x}( \pm s)$

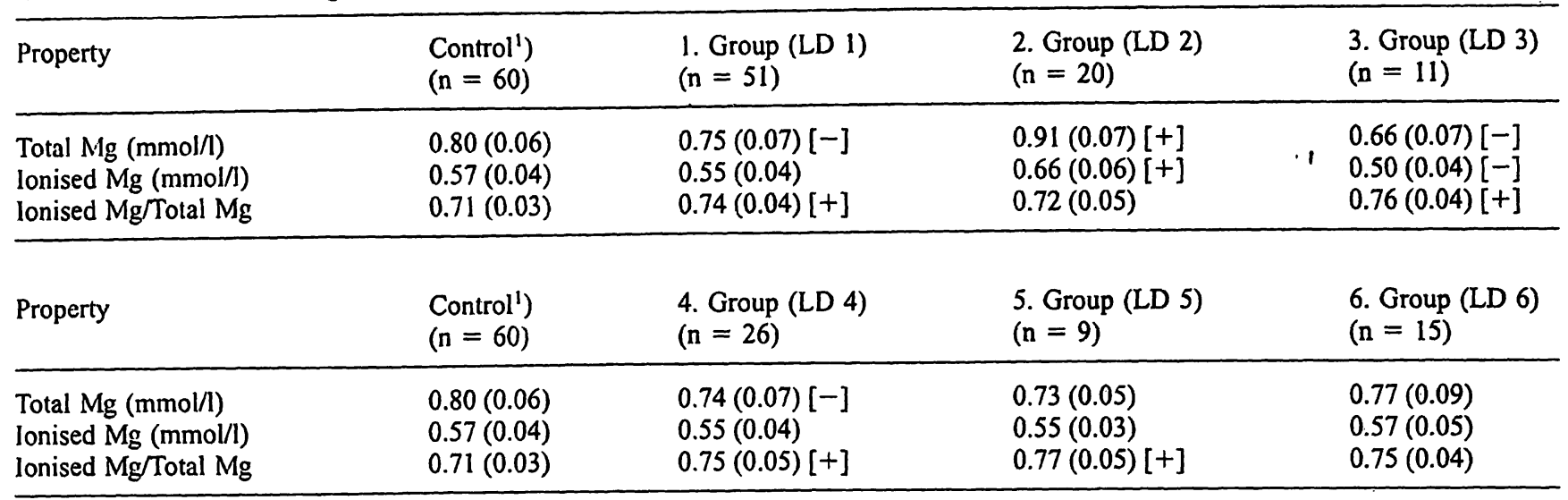

[ ] Statistically significant negative [ $[-]$ or positive $[+]$ deviation as compared with the mean of the control group

1) Control: Reference group of healthy blood donors

LD 1: Liver disease

LD 2: Liver disease; creatinine concentration in the serum exceeding the reference interval

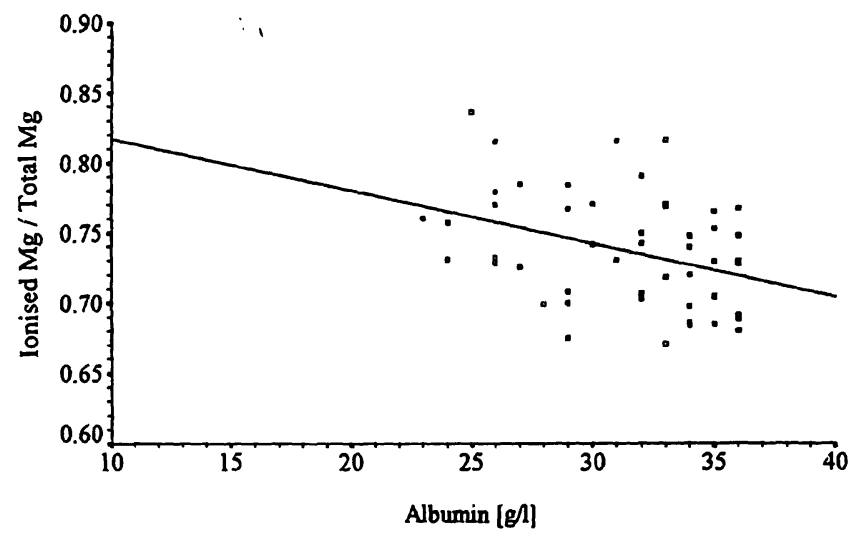

Fig. 3 Fraction of ionised $\mathrm{Mg}$ and albumin in liver diseases (LD 1)

Slope: -0.004 Intercept: 0.86 Coefficient of correlation: -0.36 LD 1: Liver disease.

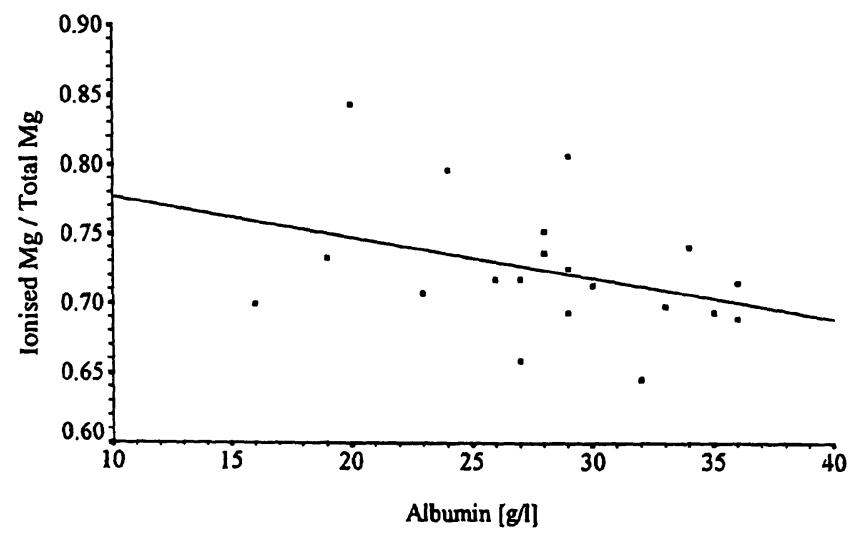

Fig. 4 Fraction of ionised $\mathrm{Mg}$ and albumin in liver diseases (LD 2)

Slope: -0.003 Intercept: 0.81 Coefficient of correlation: -0.35 LD 2: Liver disease and renal insufficiency.

\section{Renal diseases}

In patients with "normal" serum creatinine concentration and proteinuria ( $\mathrm{RD} 1$ ) it may be supposed that the total magnesium concentration is lowered due to hypoalbu-
LD 3: Orthotopic liver transplantation; treatment with cyclosporin LD 4: Liver disease; treatment with furosemide and spironolactone LD 5: Liver disease; treatment with spironolactone

LD 6: Liver disease; treatment with furosemide, spironolactone and magnesium salt p. 0 .

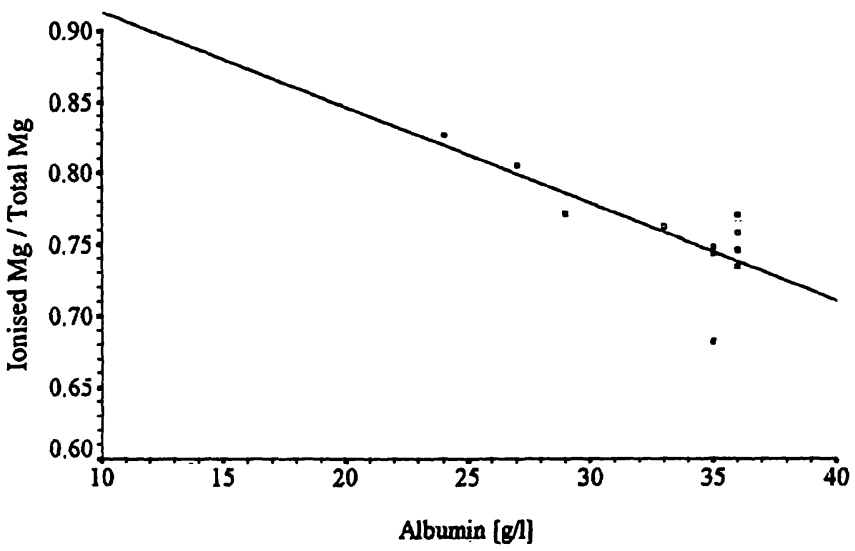

Fig. 5 Fraction of ionised $\mathrm{Mg}$ and albumin in liver diseases (LD 3)

Slope: -0.007 Intercept: 0.98 Coefficient of correlation: -0.77 LD 3: Orthotopic liver transplantation; treatment with cyclosporin.

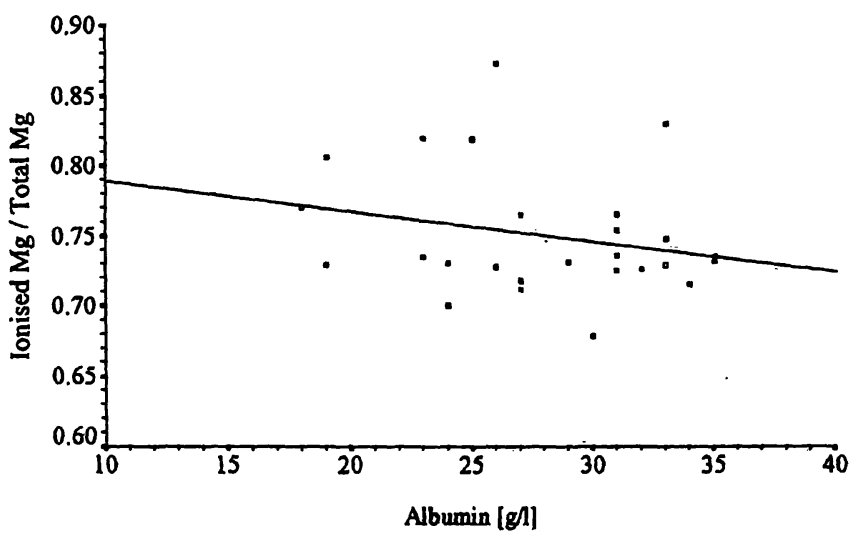

Fig. 6 Fraction of ionised $\mathrm{Mg}$ and albumin in liver diseases (LD 4)

Slope: -0.002 Intercept: 0.81 Coefficient of correlation: -0.24 LD 4: Liver disease; treatment with furosemide and spironolactone.

minaemia ("pseudohypomagnesaemia"). Indeed, the ionised magnesium concentration did not differ significantly from the normal concentration, and the ratio: ionised magnesium/total magnesium was inversely 


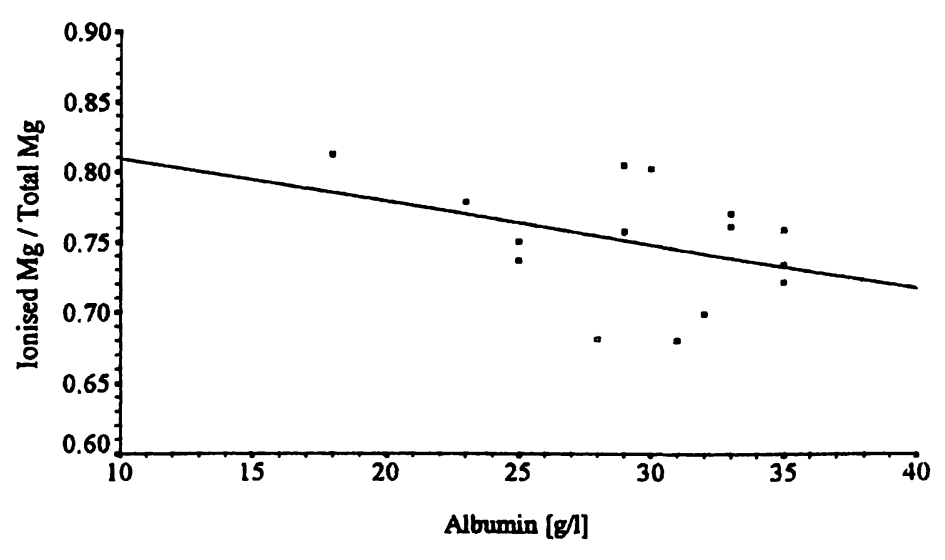

Fig. 7 Fraction of ionised $\mathrm{Mg}$ and albumin in liver diseases (LD 6)

Slope: -0.003 Intercept: 0.84 Coefficient of correlation: -0.36 LD 6: Liver disease; treatment with furosemide, spironolactone, and magnesium salt p. 0 .

correlated with the albumin concentration. This ratio minimises the impact of many other factors which similarly influence total and ionised magnesium. Hence it can be more clearly demonstrated that albumin concentration only affects the total magnesium concentration, i. e. total magnesium concentration was directly correlated with the albumin concentration. Of course, the correlation was not very strong, as ionised and total magnesium are more closely related.

In renal insufficiency, hypermagnesaemia was observed due to a reduced glomerular filtratation rate of ultrafilterable magnesium, which was only partly counterbalanced by an increased fractional excretion rate. As ionised magnesium is the most important fraction of ultrafilterable magnesium, its concentration also rose, as well as the concentration of total magnesium which is in equilibrium with ionised magnesium. Apart from the decisive influence of renal function on the magnesium concentration, the role of albumin was still demonstrable (fig. 2), with the ionised magnesium fraction inversely correlated with the albumin concentration.

\section{Liver diseases}

In liver diseases associated with hypoalbuminaemia and normal renal function (LD 1), "pseudohypomagnesaemia" may be diagnosed for the same reasons as in the $\mathrm{RD}$ 1-group. The changes were less distinct, as hypoalbuminaemia was less pronounced. In cases of concomitant renal insufficiency, changes resembled those in the RD 2-group - with albumin still exerting an influence.

In patients treated with cyclosporin (LD 3) renal loss of (ultrafilterable) magnesium was evident. Both the ionised and the total magnesium concentration were lowered. However, due to hypoalbuminaemia, the decrease of total magnesium exceeded the decrease of ionised magnesium and the fraction of ionised magnesium was elevated.
During treatment with an aldosterone antagonist alone or in combination with furosemide (LD 4, LD 5), a normal ionised magnesium concentration was maintained, whereas the total magnesium concentration (affected by the decreased albumin concentration) suggested magnesium deficiency. If treatment with an aldosterone antagonist was accompanied by magnesium administration, the ionised magnesium concentration exceeded (not significantly) the normal concentration; the total magnesium concentration was closer to normal, but it did not attain a normal value on account of the reduced proteinbound fraction.

It may be concluded that an increased concentration of total magnesium is usually accompanied by an increase of ionised magnesium, e.g. in renal insufficiency. A decreased total magnesium concentration is quite often the result of "pseudohypomagnesaemia", which arises from hypoalbuminaemia with a normal ionised magnesium concentration. Among the patients investigated, a decreased ionised magnesium concentration was observed only in patients receiving cyclosporin, i. e. these patients suffered a true magnesium deficiency due to renal loss. As "true" hypomagnesaemia (i. e. decreased ionised magnesium concentration) was not observed in the more severe stages of renal and hepatic diseases with distinct hypoalbuminaemia, it may be assumed that the less serious stages are also not associated with "true" hypomagnesaemia. This means that "true" hypomagnesaemia is not to be expected in renal diseases, whereas "true" hypermagnesaemia is likely to develop in cases of reduced glomerular filtration rate.

In the same way severe liver diseases with or without treatment with diuretics (furosemide and/or spironolactone) usually do not lead to "true" hypomagnesaemia, apart from cyclosporin treatment after orthotopic liver transplantation. The influence of free fatty acids is obviously of minor importance. The investigated diseases are not typically accompanied by a change in free fatty acid concentration. A decrease of ionised magnesium concentration was not encountered, except in cyclosporin treatment when it paralleled the total magnesium concentration. Therefore, it is recommended that decreased total magnesium concentrations are further investigated by measurement of the ionised magnesium concentration. Calculation of ionised magnesium from total magnesium and albumin may be erroneous for the same reasons that an analogous calculation of ionised calcium is erroneous. Administration of magnesium should be monitored by measurement of the ionised magnesium concentration, which reflects the physiologically active fraction of magnesium and assists in detecting inactivation by complexing agents. It may help to decide whether patients may benefit from administration of magnesium and increased magnesium concentrations. 


\section{References}

1. Maj-Zurawska M, Lewenstam A. Fully automated potentiometric determination of ionized magnesium in blood serum. Anal Chim Acta 1990; 236:331-5.

2. Külpmann WR, Kallien T, Lewenstam A. Evaluation of an ionselective electrode for the determination of "ionized" magnesium. In: D'Orazio P, Burritt MF, Sena SF, editors. Electrolytes, blood gases, and other critical analytes: the patient, the measurement, and the government. Madison: Omnipress, 1992:188-211.

3. Eugster R, Rusterholz B, Schmid A, Spichiger UE, Simon W. Characterization procedure for ion-selective electrode assays of magnesium activity in aqueous solutions of physiological composition. Clin Chem 1993; 39:855-9.

4. Altura BT, Shirey TL, Young CC, Dell'Orfano K, Altura BM. Characterisation of a new ion selective electrode for ionized magnesium in whole blood, plasma, serum and aqueous samples. Scand J Clin Lab Invest 1994; 54 Suppl 217:21-6.

5. Altura BT, Altura BM. A method for distinguishing ionized, complexed and protein-bound $\mathrm{Mg}$ in normal and diseased subjects. Scand J Clin Lab Invest 1994; 54 Suppl 217:83-7.

6. Van Ingen HE, Huijgen HJ, Kok WT, Sanders GTB. Analytical evaluation of Kone Microlyte determination of ionized magnesium. Clin Chem 1994; 40:52-5.

7. Ising H, Bertschat $F$, Günther T, Jeremias E, Jeremias A. Measurement of free magnesium in blood, serum and plasma with an ion-sensitive electrode. Eur J Clin Chem Clin Biochem 1995; 33:365-71.

8. Külpmann WR, Rademacher E, Bornscheuer A. Concentration of ionized magnesium in serum during liver transplantation. Magnesium-Bull 1993; 15:134-5.

9. Wissenschaftlicher Beirat der Bundesärztekammer und Bundesgesundheitsamt. Richtlinien zur Bilutgruppenbestimmung und Bluttransfusion. Köln: Deutscher Ärzte-Verlag, 1991.

10. Scheffé $H$. A method for judging all contrasts in the analysis of variance (published errata appear in Biometrika 1969; 56:229). Biometrika 1953; 40:87-104.

11. Bundesärztekammer. Qualitätssicherung der quantitativen Bestimmungen im Laboratorium. Dtsch Ärztebl 1988; 85:A697-A-711.

12. Speich M, Bousquet B, Nicolas G. Reference values for ionized, complexed, and protein-bound plasma magnesium in men and women. Clin Chem 1981; 27:246-8.

13. Maj-Zurawska M, Hulanicki A, Drygieniec D, Pertkiewicz M. Ionized and total magnesium level in blood serum and plasma of healthy and ill adults. Elektroanalysis 1993; 5:713-7.

Received October 2/December 11, 1995

Corresponding author: Prof. Dr. W. R. Külpmann, Institut für Klinische Chemie, Medizinische Hochschule Hannover, Konstanty-Gutschow-Straße 8, D-30625 Hannover, Germany 